\title{
Geology and petrology of the Simav Magmatic Complex (NW Anatolia) and its comparison with the Oligo-Miocene granitoids in NW Anatolia: implications on Tertiary tectonic evolution of the region
}

\author{
Erhan Akay
}

Published online: 31 July 2008

(C) Springer-Verlag 2008

Erratum to: Int J Earth Sci (Geol Rundsch)

DOI 10.1007/s00531-008-0325-0

Unfortunately Article "Ilbeyli et al. (2007) Geochemical constraints on the genesis of collision-related intrusive rocks from western Anatolia, Turkey. Int J Earth Sci. doi: $10.1007 / \mathrm{s} 00531-006-0103-9$ " is withdrawn by the authors. Therefore the article is not valid anymore. Instead of Ilbeyli et al. (2007), please see Aydoğan et al. (2005) which is already cited in the text.

The online version of the original article can be found under doi:10.1007/s00531-008-0325-0.

E. Akay $(\square)$

Department of Geological Engineering, Dokuz Eylul University,

Engineering Faculty, Tinaztepe, 35160 Buca, Izmir, Turkey

e-mail: erhan.akay@deu.edu.tr 